\title{
Assessment of pesticide residue on cocoa beans in Ondo State, Nigeria
}

\author{
Joseph 0. Akinneye*, Oluwakemi A. Adeleye, Femi P. Adesina and \\ Makanjuola I. Akinyemi
}

Department of Biology, Federal University of Technology Akure, Ondo State, Nigeria. *Email: josephakinneye@yahoo.co.uk.

\begin{abstract}
The use of pesticides for effective pests control has generated a lot of concerns relating to public health and environmental pollution. With the new European Union (EU) Legislation on Maximum Residue Levels (MRLs) allowed on cocoa beans and its products, this study aimed to assess the pesticide residue on cocoa beans from Ondo State, Nigeria. Dry cocoa beans were collected from four different towns having cocoa farm industries in Ondo State, Nigeria. The five locations are Akure, Idanre, Ondo and Ore. Assessment of pesticide usage was done using structured questionnaires to obtain information on the extent of use of pesticides. Pesticide Residues was carried out using GCMS and retention times were used for identification of pesticides and quantified using external calibration method. Generally, the $\mathrm{pH}$ of the cocoa beans from the four locations was less acidic, pH ranging 5.90-5.60 and moisture content of cocoa beans sample from Akure was significantly different $(p<0.05)$ from other three locations with highest moisture content (6.60\%). Majorly, $94.2 \%$ of the farmers were affected by pests and $71.6 \%$ of the farmers resolved in using pesticides in solving this challenge. There were no active ingredients of pesticide residue detected from these four locations except the inert ingredients. Absence of active ingredients of pesticides in the sampled cocoa beans implies that pesticide residue is phasing out gradually in cocoa industry in Ondo State.
\end{abstract}

Keywords: Cocoa beans; Pests; Pesticide residues; Active ingredients; Maximum residue levels; MRLs.
Received

June 11, 2018

Accepted

August 8, 2018

Released

August 31, 2018

Full Text Article

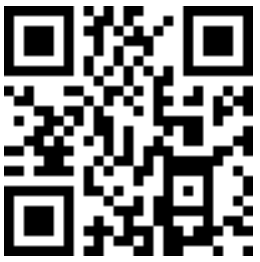

\footnotetext{
ORCID

가 $0000-0002-2672-1856$ Joseph 0. Akinneye

(1) 0000-0002-7573-1508 Oluwakemi A. Adeleye

(D) 0000-0001-6370-1531

Femi P. Adesina

(1) 0000-0002-1161-4003

Makanjuola I.

Akinyemi
}

\section{Introduction}

In Sub-Saharan countries, including Nigeria, agriculture is considered to hold the key to economic development. The Nigeria cocoa economy has a rich history has it was ranked among one of the highest cocoa producers in the world. Many authors have reported the role play by cocoa production in the economy development of this Nation (Folayan et al., 2006; Fadipe et al., 2012). Before the discovery of the crude oil in 1970's, cocoa was the 
main agricultural produce that sustained Nigeria economy. Among other agricultural commodity export of the country, cocoa has remained a valuable crop and major foreign exchange earner (Ajayi and Oyejide, 1974; ICCO, 2001). In addition, Taubert et al. (2007) reported cocoa has a plant-based food that contains carbohydrates, fats, proteins, natural minerals and some vitamins that are of benefits to human health.

Pesticides have contributed significantly to food security in the world, for controlling and destroying various types of pests. Unfortunately, Nigeria's cocoa production has over the years faced major challenges (Aikpokpodion et al., 2012). Among these challenges is the incidence of insect pests and diseases which has been recognized as one of major causes of declining yields in cocoa production. In order to increase cocoa yields, the use of synthetic pesticide has been a measure to control its pest and disease. The use of pesticides is becoming more widespread in Nigeria and its application is more concentrated on cocoa, oil palm, cereals, vegetables and fruits sectors. On the other hand, their use has often been associated with unintended environmental and human health consequences (Dankyi et al., 2014; Owombo et al., 2014). Ignorance, lack of safety concerns and lack of effective regulations on chemical usage in most of the developing country have resulted in the misuse and overuse of the chemicals (Oduwole, 2001; Fianko et al., 2011).

Tijani and Sofoluwe in 2012 established that farmers in Nigeria are not adopting the technical knowledge developed from scientific research on cocoa pest management properly. Many farmers did not know a specific dosage that is cost effective and which can also minimize the quantity of the residues that the pesticide will leave on the crop. Inappropriate application of these pesticides leaves residues on cocoa hence serving as a contaminant (Asogwa and Dongo, 2007). Adverse human health effects like endocrine disruption, reproductive failures and birth defects, immune system malfunction, Parkinson's disease and cancers had been identified to be caused by Chlordane, Heptachlor, DDT, DDE and Endosulfan (Afful et al., 2010; Okoya et al., 2013). Cocoa beans with pesticide residue level above the stipulated Maximum Residue Limits (MRL) are likely to be rejected from international trade. Therefore it is necessary to determing the pesticide residues level in food and cash crops like cocoa for the safety of the populace. In this study, the main objective is to assess and determine the levels of pesticide residues in cocoa beans in Ondo State.

\section{Materials and methods}

\section{Area of study}

Ondo State is located in the Southwestern geopolitical zone of Nigeria (Figure 1) and bounded in the North by Ekiti and Kogi States, in the East by Edo State, in the west by Osun and Ogun states and in the south by the Atlantic Ocean. Ondo State is located entirely within the tropics.

\section{Sources of materials}

Dry cocoa beans were collected from four prominent towns for cocoa production in Ondo State, Nigeria.The towns are Akure, Idanre, Ondo and Ore (Figure 1). Authentication of cocoa beans were done in Crop and Soil Production Department, Federal University of Technology Akure, Ondo State, Nigeria.

\section{content \\ Determination of moisture}

Moisture in the beans was determined using the International Organisation for Standards (ISO) method. Approximately $10 \mathrm{~g}$ of ground bean sample was placed into a pre-weighed dish (W1) with a lid and re-weighed to the nearest mg (W2). Dishes and contents were put in an oven at $103{ }^{\circ} \mathrm{C} \pm$ $2{ }^{\circ} \mathrm{C}$ for $16 \mathrm{~h}$. After cooling in desiccators 
they were weighed (W3) and the percentage moisture content was calculated using the following formula:

$$
\frac{\left(\mathrm{W}_{2}-\mathrm{W}_{1}\right)}{\left(\mathrm{W}_{2}-\mathrm{W}_{3}\right)} \quad \times 100
$$

\section{Assessment of pesticide usage}

Interview schedule and well structured questionnaires were used to obtain information on the extent of use of pesticides, farmers' knowledge of pesticides, and their awareness about the banned pesticides. 30 farmers were randomly selected from each studied areas in Ondo State, making 120 respondents enrolled for this study.

\section{residues}

\section{Quantification of pesticide}

Sample preparation (in three replicates), extraction, clean-up and analysis were carried out according to the procedure described in multi-residue method for agricultural chemicals with slight modifications (Syoku-An, 2006). The residue levels of all the pesticides were quantitatively determined by the external standard method using peak area. Gas chromatographic (GC) conditions for analysis of pesticide residues was done and the organochlorine and synthetic pyrethroids pesticide residues were analyzed by Gas Chromatograph-Varian CP-3800 equipped with a mass-selective detector (GC-MS). Additionally, the quality of pesticides residues was assured through the analysis of solvent blanks, procedural matrix blanks and triplicate samples. Measurement was carried out within the linear range of the detector. The peak areas whose retention times coincided with the standards were extrapolated on their corresponding calibration curves to obtain the concentration.

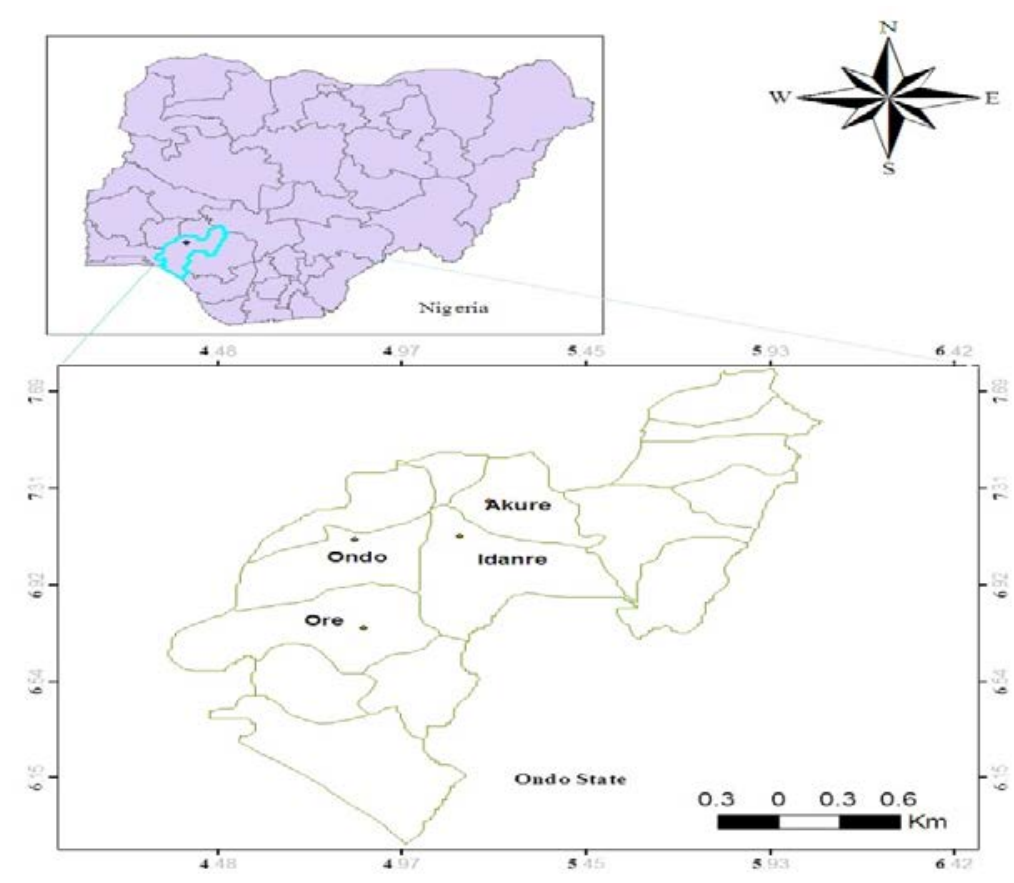

Figure 1. A map showing the geographical location of the studied areas. 


\section{Result}

Moisture content (Figure 2) of cocoa beans sample from Akure was significantly different $(p<0.05)$ from other three locations with highest moisture content $(6.60 \%)$.

Table 1 shows the pesticide residual analysis carried out on cocoa beans from Idanre using gas chromatograph mass spectrophotometer
(GCMS). Five ingredients were detected from the sample. 12-octadecenoic acidmethyl ester had the highest total percentage Area (27.48\%) with retention rate of 13.56 while 2-oxo-3-methyl-cisperhydro-1-3-benzoxazine had the smallest area percentage with retention time of 13.50. The chromatogram of sample from Idanre was shown in Figure 3.

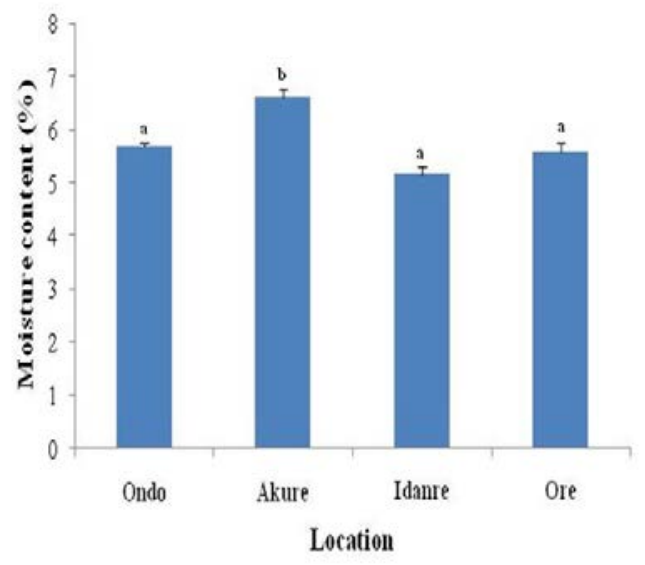

Figure 2. Moisture content of cocoa beans sampled from four different towns in Ondo Sate.

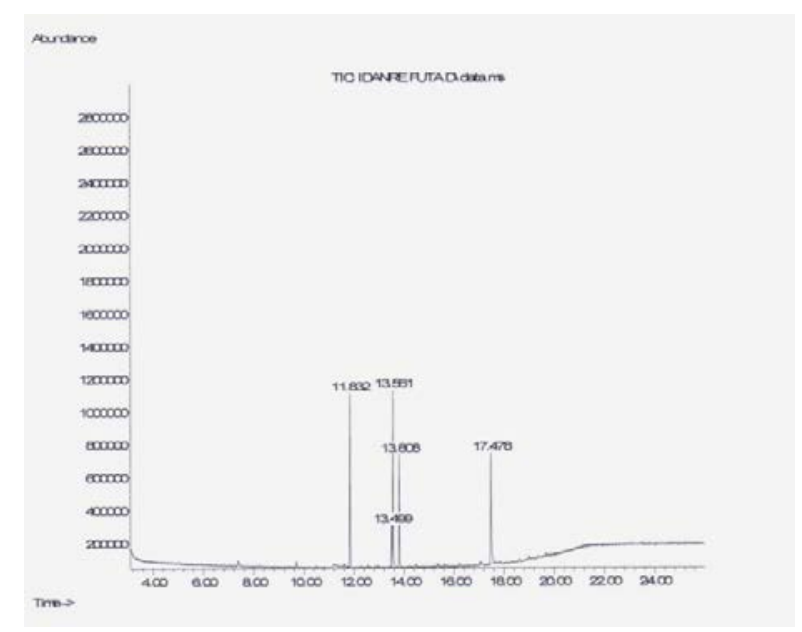

Figure 3. GC-MS Chromatogram showing the active ingredient peak of Idanre cocoa beans.

Table 1. GCMS analysis of cocoa beans from Idanre.

\begin{tabular}{lllll}
\hline & \multicolumn{1}{c}{ Active Ingredient } & \multicolumn{1}{c}{ RT } & \multicolumn{1}{c}{ CAS } & \multicolumn{1}{c}{ Area \% } \\
\hline 1 & Hexadecanoic acid, methyl esther & 11.83 & $000112-39-0$ & 24.50 \\
2 & 2-oxo-3-methyl-cis-perhydro-1,3-benzoxazine & 13.50 & $1000138-84-6$ & 6.46 \\
3 & 12-octadecenoic acid, methyl ester & 13.56 & $056554-46-2$ & 27.48 \\
4 & Methylstearate & 13.81 & $000112-61-8$ & 17.49 \\
5 & Bis (2-ethylhexyl) phthalate & 17.48 & $000117-81-7$ & 24.07 \\
\hline
\end{tabular}

RT - Retention Time; CAS - Chemical Abstract Service Number.

Six ingredient of pesticide residue were detected from Ore cocoa bean sample (Table 2). The highest total area percentage was recorded with 8octadecenoic acid-methyl ester (30.95) with retention time of 13.57 and the least area percentage was in caffeine (5.16) with retention time of 11.07 . The chromatogram of residue detected was shown in Figure 4. 
Table 2. GCMS analysis of cocoa beans from Ore.

\begin{tabular}{llccc}
\hline & \multicolumn{1}{c}{ Active Ingredient } & RT & CAS & Area \% \\
\hline $\mathbf{1}$ & Caffeine & 11.07 & $000058-08-2$ & 5.16 \\
$\mathbf{2}$ & Hexadecanoic acid, methyl ester & 11.84 & $000112-39-0$ & 19.53 \\
$\mathbf{3}$ & Methyl 9-cis, 11-trans-octadecadienoate & 13.51 & $1000336-44-0$ & 6.71 \\
$\mathbf{4}$ & 9-octadecenoic acid, methyl ester & 13.57 & $026528-50-7$ & 30.95 \\
$\mathbf{5}$ & Methyl stearate & 13.81 & $000112-61-8$ & 16.50 \\
$\mathbf{6}$ & Bis (2-ethylhexyl) phthalate & 17.48 & $000117-81-7$ & 21.15 \\
\hline
\end{tabular}

RT - Retention Time; CAS - Chemical Abstract Service Number.

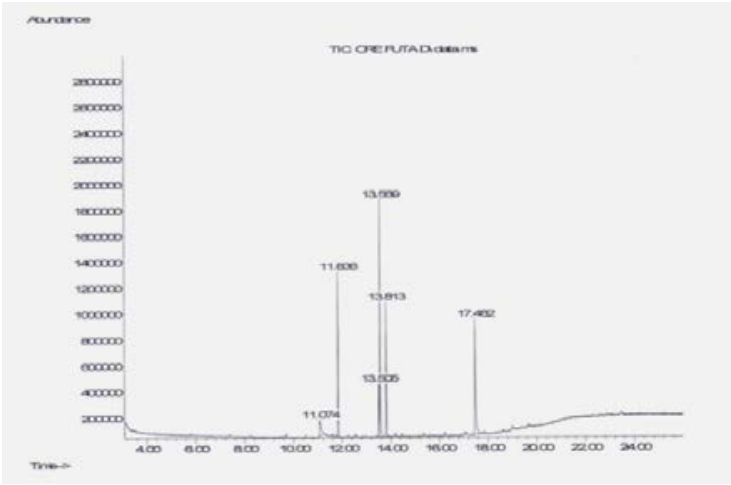

Figure 4. GC-MS Chromatogram showing the active ingredient peak of Ore cocoa beans.

In Table 3, pesticide residue analysis shown five other ingredients from Ondo cocoa beans sample, 8octadecanoic acid-methyl ester-(E) had the highest percentage area (37.27) with retention time of 13.57 and the compound having the least percentage area was Bis(2-ethylhexyl)phthalate (6.03) with retention time of 17.48. The chromatogram of cocoa beans sample from Ondo was shown in Figure 5.

GC-MS shown six other ingredients of pesticides from cocoa beans sample from Akure (Table 4), 8octadecanoic acid- methyl ester-(E) had the highest percentage area (30.34) with retention time of 13.57 and the lowest percentage was 2-Ethoxyamphetamine (2.39) of 11.3 retention time. The Chromatogram of compound detected in cocoa bean sample from Akure was shown in Figure 6.

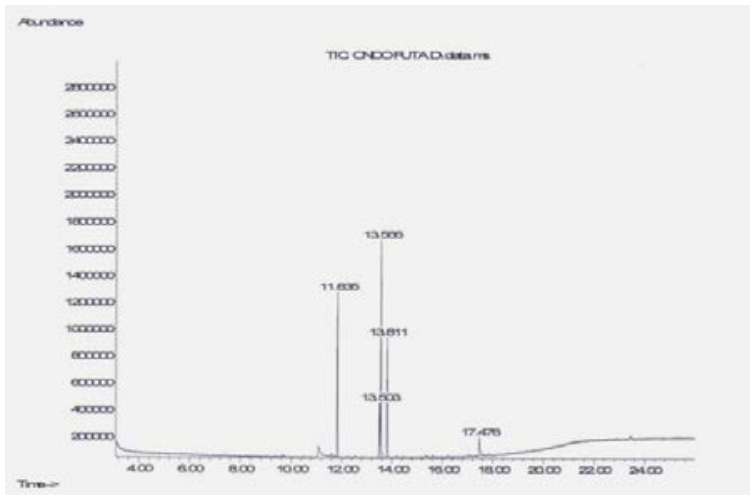

Figure 5. GC-MS Chromatogram showing the active ingredient peak of Ondo cocoa beans.

Cocoa bean samples from all the four cocoa growing towns did not contain the organochlorines, organophosphorus, carbamate, and Pyrethroids tested for. The pesticide residue was below detectable levels and European Maximum Residue Limit (EU MRLs) (Tables 5, 6 and 7).

Majority of the synthetic pesticide (insecticides and fungicides) used by the cocoa farmer in the studied area in Ondo State were synthetic pyrethroids and organophosphorus (Table 8). The active ingredient in the insecticide was majorly cypermethrin but some also have profenofos, tetramethrin, lambda-cyhalothrin and dimethoate. While the active ingredients in the fungicides were Metalaxyl and Copper (1) oxide. 


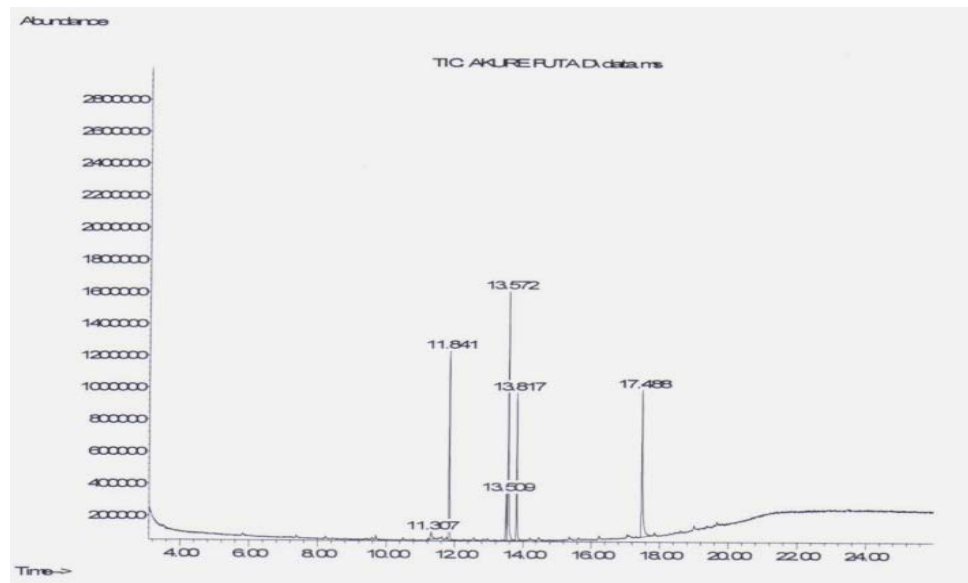

Figure 6. GC-MS Chromatogram showing the active ingredient peak of Akure cocoa beans.

Table 3. GCMS analysis of cocoa beans from Ondo.

\begin{tabular}{llccc}
\hline & Active Ingredient & RT & CAS & Area \% \\
\hline 1 & Hexadecanoic acid, methyl ester & 11.83 & $000112-39-0$ & 27.5 \\
2 & Methyl 9-Cis, 11-trans-octadecadienoate & 13.50 & $1000336-44-0$ & 9.22 \\
3 & 9-octadecanoic acid, methyl ester, (E) & 13.57 & $026528-50-7$ & 37.27 \\
4 & Methyl stearate & 13.81 & $000112-61-8$ & 20.03 \\
5 & Bis(2-ethylhexyl)phthalate & 17.48 & $000117-81-7$ & 6.03 \\
\hline
\end{tabular}

RT - Retention Time, CAS - Chemical Abstract Service Number.

Table 4. GCMS analysis of cocoa beans from Akure.

\begin{tabular}{llccc}
\hline & \multicolumn{1}{c}{ Active Ingredient } & RT & CAS & Area \% \\
\hline 1 & 2-Ethoxyamphetamine & 11.31 & $135014-84-5$ & 2.39 \\
2 & Hexadecanoic acid methyl ester & 11.84 & $000112-39-0$ & 21.13 \\
3 & Piperidine,3-(bromomethyl) & 13.51 & $1000362-63-2$ & 5.26 \\
4 & 9-octadecanoic acid, methyl ester, (E) & 13.57 & $026528-50-7$ & 30.34 \\
5 & Methyl stearate & 13.82 & $000112-61-8$ & 16.97 \\
6 & Bis(2-ethylhexyl)phthalate & 17.49 & $000117-81-7$ & 23.91 \\
\hline
\end{tabular}

RT - Retention Time, CAS - Chemical Abstract Service Number.

Table 5. Quantity of organochlorine residue on cocoa bean from four locations in Ondo State.

\begin{tabular}{lccccc}
\hline Organochlorine & EU MRLs (mg/kg) & Ondo & Akure & Idanre & Ore \\
\hline DDT & $0.50(\operatorname{Max})$ & ND & ND & ND & ND \\
Endosulphan & $0.10(\operatorname{Max})$ & ND & ND & ND & ND \\
Aldrin & $0.05(\operatorname{Max})$ & ND & ND & ND & ND \\
Dieldrin & $0.50(\operatorname{Max})$ & ND & ND & ND & ND \\
Chlordane & $0.02(\operatorname{Max})$ & ND & ND & ND & ND \\
HCH & $0.02(\operatorname{Max})$ & ND & ND & ND & ND \\
Heptachlor & $0.02(\operatorname{Max})$ & ND & ND & ND & ND \\
Lindane & $1.00(M a x)$ & ND & ND & ND & ND \\
Endrine & $0.01(M a x)$ & ND & ND & ND & ND \\
\hline
\end{tabular}

ND - Not detected. 
Table 6. Quantity of organophosphorus residue on cocoa bean from four locations in Ondo State.

\begin{tabular}{|c|c|c|c|c|c|}
\hline Organophosphorus & EU MRLs (mg/kg) & Ondo & Akure & Idanre & Ore \\
\hline Malathion & $0.02(\mathrm{Max})$ & ND & ND & ND & ND \\
\hline Dimethoate & 0.05 (Max) & ND & ND & ND & ND \\
\hline Diazinon & 0.02 (Max) & ND & ND & ND & ND \\
\hline Fenitrothrion & 0.20 (Max) & ND & ND & ND & ND \\
\hline Methemidophos & 0.02 (Max) & ND & ND & ND & ND \\
\hline Parathion & 0.10 (Max) & ND & ND & ND & ND \\
\hline Pirimiphos methyl & 0.05 (Max) & ND & ND & ND & ND \\
\hline Phorate & 0.10 (Max) & ND & ND & ND & ND \\
\hline Ethoprophos & 0.02 (Max) & ND & ND & ND & ND \\
\hline
\end{tabular}

ND - Not detected.

Table 7. Quantity of Pyrethroids residue on cocoa bean from four locations in Ondo State.

\begin{tabular}{lccccc}
\hline Pyrethroids & EU MRLs (mg/kg) & Ondo & Akure & Idanre & Ore \\
\hline Bifenthrin & 0.10 (Max) & ND & ND & ND & ND \\
Cyhalothrin & 0.05 (Max) & ND & ND & ND & ND \\
Permethrin & $0.01(M a x)$ & ND & ND & ND & ND \\
Cypermethrin & 0.01 (Max) & ND & ND & ND & ND \\
Fenvalerates & 0.05 (Max) & ND & ND & ND & ND \\
Deltamethrin & 0.05 (Max) & ND & ND & ND & ND \\
Cyfluthrin & 0.01 (Max) & ND & ND & ND & ND \\
\hline
\end{tabular}

ND - Not detected.

Table 8. Synthetic pesticides used on cocoa farm in the studied area.

\begin{tabular}{ll}
\hline Trade name & Active Ingredient \\
\hline Insecticides & \\
Avesthrin & Cypermethrin 10EC 100G/L \\
Sharp shooter & Cypermethrin 4\% and Profenofos $40 \%$ \\
Cyperforce & Cypermethrin $10 \%$ \\
Sanitox & Cypermethrin $7 \%+$ Tetramethrin. 3\% \\
Magic force & Lambda-Cyhalothrin 15 g / L + Dimethoate 300 g / L EC \\
Fungicide & Metalaxyl M 6\%WP and Copper (1) oxide 60\% \\
Red force & Metalaxyl and Copper (1) oxide \\
Mackeckine Gold & Metalaxyl and Copper (1) oxide \\
Red bolt & Metalaxyl -M 60\% and Copper (1) oxide 60\% \\
Ridomil Gold & Metalaxyl 12\% and Copper (1) oxide 60\% \\
Ultimax plus &
\end{tabular}

Table 9 shown the assessment of pesticide usage in Ondo State gathered from the four studied locations. A total of 120 questionnaires were distributed among the farmers while hundred percent $(100 \%)$ of the questionnaires were well treated and returned. Majority
(78.3\%) of the cocoa farmers was educated and $94.2 \%$ of the farmers were affected by pests. More than half $(71.6 \%)$ of the farmers resolved in using pesticides in solving this challenge and none of these farmers $(0.0 \%)$ applied chemical pesticide directly on their cocoa 
beans but $98.3 \%$ of the farmers identified treating the cocoa seed for pest control before planting. Apart from synthetic pesticide, $67.5 \%$ of the farmer used Integrated Pest management (IPM) for the control of pests while 30.8\% mentioned locally made/botanical as alternative method used. In order to control pest on their farm, $94.1 \%$ affirmed of consulting expert and $96.7 \%$ of the cocoa farmers were fully aware that some pesticides were banned for cocoa farming in Nigeria.

Table 9. Assessment on pesticide usage in Ondo State.

\begin{tabular}{|c|c|c|}
\hline Variables & Option & Outcome \\
\hline \multirow{2}{*}{ Educational status } & Educated & $78.3 \%$ \\
\hline & Not Educated & $21.7 \%$ \\
\hline \multirow[t]{2}{*}{ Is your crop affected by pest? } & Yes & $94.2 \%$ \\
\hline & No & $5.8 \%$ \\
\hline \multirow{3}{*}{$\begin{array}{l}\text { How frequently is your crop being } \\
\text { affected by pest? }\end{array}$} & Once every crop & $47.5 \%$ \\
\hline & More than once every crop & $52.5 \%$ \\
\hline & None & $0.0 \%$ \\
\hline \multirow[t]{2}{*}{ Do you use pesticide in your farm? } & Yes & $71.6 \%$ \\
\hline & No & $28.4 \%$ \\
\hline \multirow{2}{*}{$\begin{array}{l}\text { Do you apply chemical pesticide directly } \\
\text { on your cocoa beans }\end{array}$} & Yes & $0.0 \%$ \\
\hline & No & $100 \%$ \\
\hline \multirow{3}{*}{$\begin{array}{l}\text { How frequently do you use pesticides in } \\
\text { your farm? }\end{array}$} & Twice in a year & $38.3 \%$ \\
\hline & Four times in a year & $53.3 \%$ \\
\hline & More than four time in a year & $8.4 \%$ \\
\hline \multirow{2}{*}{$\begin{array}{l}\text { Do you treat the seeds before sowing for } \\
\text { pest control? }\end{array}$} & Yes & $98.3 \%$ \\
\hline & No & $1.7 \%$ \\
\hline \multirow{3}{*}{$\begin{array}{l}\text { What alternative methods do you use to } \\
\text { control pest? }\end{array}$} & Bio pesticide & $1.7 \%$ \\
\hline & Locally made/Botanical pesticide & $30.8 \%$ \\
\hline & Integrated Pest Management & $67.5 \%$ \\
\hline \multirow{3}{*}{$\begin{array}{l}\text { How often do you meet experts for } \\
\text { consultation to control pests? }\end{array}$} & Before cultivation & $50.8 \%$ \\
\hline & During Cultivation & $43.3 \%$ \\
\hline & Never & $5.9 \%$ \\
\hline \multirow{2}{*}{$\begin{array}{l}\text { Have you undergone any training on pest } \\
\text { control? }\end{array}$} & Yes & $85.8 \%$ \\
\hline & No & $14.2 \%$ \\
\hline \multirow{2}{*}{$\begin{array}{l}\text { Are you aware some pesticides are } \\
\text { banned in Nigeria? }\end{array}$} & Yes & $96.7 \%$ \\
\hline & No & $3.3 \%$ \\
\hline
\end{tabular}

\section{Discussion}

The moisture content of cocoa beans is very important before and during the storage. The moisture content of the studied cocoa beans from Ondo State was within the maximum moisture content of $7.5 \%$ discussed by Lærke, 2010 , this is a precaution to minimize mould and pest invasion. Abiola and Tewe (1991) reported that the key factor for long shelf-life in cocoa beans is the control of the moisture content.

This study revealed that pest is one of the challenges of cocoa production in this area, as majority of the farmer mentioned. CRIN, 2008 and Iremiren, 2011also related insect pests and diseases as one of the paramount importance problems faced on cocoa production in Nigeria. In other to solve these problems associated with cocoa 
farming, cocoa farmers from this area engaged in using synthetic pesticides and other alternatives like Bio-pesticide, locally made (Botanical) pesticide and Integrated Pest Management (IPM). Synthetic pesticide like avestrin (Cypermethrin 10\%), sharp shooter, red force, ultimas plus and sanitox were been used by these farmers and these belong to the four main groups of pesticides (Smith, 2002; Ahmed et al., 2000) that are of particular concern because of their toxicity and persistence in the environment.

There was no active ingredients of pesticide residue detected from the four locations in Ondo State and this may be as a result of proper training on pesticide application that been identified by the responds received from the respondent farmers. Again there was no direct application of synthetic pesticide on cocoa beans by these farmers except on the farm. In contrary, Mulungu et al. (2007) reported that farmers do treat their produce with synthetic insecticides during storage whereas majority of them still lack the knowledge on proper, safe and effective use. High levels of pesticides residues arising from improper application and multiple sprays of sub lethal doses have been reported to be responsible for the poisoning and deaths of people in both rural and urban areas of Borno State and Nigeria in general (Gwary et al., 2012).

At each studied town, cocoa farmers association is a prominent organization in which their members gather together often time for a meeting, during which this organization educate and train his member on cocoa production. This was in agreement with the findings of Famuyiwa et al., 2014 that farmers may be more oriented to environmental hazards of pesticides due to their sources of information (organization). Also, Oduwole (2001) attributed that one major benefit of belonging to organization is the share of knowledge on innovation and this aids adoption as information about the innovation are shared among peers. The cocoa warehouse company where these farmers sell their cocoa beans revealed of not using any pesticides during the storage before exporting it to the market. The interview with the cocoa warehouse further revealed of ensuring proper quality assessment test of cocoa from the farmers before accommodating the cocoa beans into their warehouse and proper cleanliness of the warehouse to avoid pests attacks. This implies that practice of preventive measures of environmental hazards associated with cocoa production were very high in the study area.

Nevertheless, caffeine and some inert ingredients were detected by GSMS from this region. Caffeine is a natural stimulant (methylxanthines) most commonly found in some plants like cocoa but relatively low in cocoa, compared to those found in coffee and tea (USDA, 2008) . It can also be used as natural pesticide or botanical pesticide on stored agriculture produces (Nathanson, 1984; Mostakim and Khan, 2014). Caffeine acts as a chemical defense, showing repellent or toxicant properties. According to Arya et al. (2000), too much of caffeine (above $20 \mathrm{~g} /$ day) may promote headaches, migraines and high blood pressure in some individuals. For some of these inert ingredients there was no maximum residue limits for it. Effects of inert ingredients on human health and the environment depend on how much chemical is present, the length and frequency of exposure, route of exposure, health of a person and certain environmental factors (NRC, 2011). The accumulation of some of the inert ingredients of pesticide found in this study were found to be carcinogenic, like Di (2-ethylhexyl) phthalate (DEHP).

Majority of the respondents from Ore were identified using botanical pesticides/locally made as an alternative to chemical pesticides. Some of these farmers even used plant leaves that have insecticidal potential on their produce to 
distract pests. Some locally made pesticides had been reported to caused the death of so many Nigerian families in recent times (Olebunne, 2009), specifically through food contamination (Akunyili, 2007).

Farmers from this region were fully aware of some of the banned pesticides by the Cocoa Research Institute of Nigeria (CRIN). This might have accounted for their absence in this study. This was contrary to research survey carried out by Tijani and Sofoluwe, 2012 in the neighbouring state (Osun State) that some of the farmers were even using banned chemical in combination with the approved ones on their cocoa. The WHO, PAN and numerous environmental organisations propose a general and global ban of some pesticides (Northern Presbyterian Agricultural Services and Partners, 2012). However, some of the developing countries are still experiencing severe health and environmental problems due to commercial usage of banned pesticides (Ahmed et al., 2000).

Majority of the farmers had at least primary education, which is also a significant influence on farmers' perception and this may also contributed to the fact of not having active ingredients of the synthetic pesticide in this study. Adeola, 2012 suggested that this might be due to the ability of the literate farmers to read and follow the instructions on pesticides containers. Understanding such instructions might prevent them from misuse of pesticides. Level of pesticide use is also affected by the knowledge achieved by farmers. Consulting an expert on pest control will really improve the knowledge of the farmer and help in controlling pest (Mariyono and Battharai, 2009).

\section{Conclusion}

This study has revealed that pests and diseases has remained one of the challenges of cocoa production and cocoa farmers in Ondo State were not exceptional among the farmers that were using synthetic pesticide to fight this challenge. Further interview with these farmers revealed their awareness about the harmful effects of pesticides and that harmful effects of the pesticides will outweigh the beneficial ones if it is not properly handled. The respondent farmers have considerably changed from banned pesticides (chemicals) to the approved pesticides for controlling the incidence of pest and diseases.

It is important to note that this study also revealed the inert or other ingredients that been overlooked over the active ingredients. This can be so dangerous to human health if their residue present on the crop and this accumulate on a body system over time. The studied cocoa beans from Ondo State were free from active ingredients residue. Extra special care is needed for pesticides used against storage pests, in warehouses and in cocoa transport.

\section{Conflict of interest}

The authors declare that there are no conflicts of interest.

\section{References}

Abiola, S. S.; Tewe, 0. O. Chemical evaluation of cocoa by-products. Tropical Gric., v. 64, p. 335-33, 1991.

Adeola, R. G. Perceptions of environmental effects of pesticides use in vegetable production by farmers in Ogbomoso, Nigeria. Global Journal of Science Frontier Research Agriculture and Biology, v. 12, no. 4, p. 73-78, 2012.

Abbe, M. M.; Amin, I. Polyphenols in cocoa and cocoa products: Is there a link between antioxidant properties and health? Molecules, v. 13, p. 2190-2219, 2008.

Afful, S.; Anim, A. K.; Serfor-Armah, Y. Spectrum of organochlorine pesticide residues in fish samples from the Densu Basin. Research Journal of Environmental and Earth Science, v. 2, no. 3, p.133-138, 2010.

Ahmed, R. S.; Vandana Seth Pasha, S. T.; Banerjee, B. D. Influence of dietary ginger 
(Zingiber officinalis Rosc) on oxidative stress induced by Malathion in rats. Food and Chemical Toxicology, v. 38, p. 443-450, 2000.

Aikpokpodion, P.; Lajide, L.; Aiyesanmi, A. F.; Silvia, L. Residues of Dichlorodiphenyltrichloroethane (DDT) and its metabolites in cocoa beans from three cocoa ecological zones in Nigeria. European Journal of Applied Sciences, v. 4, no. 2, p. $52-57,2012$.

Ajayi, S. I.; Oyejide, T. A. The role of cocoa in Nigeria economic development. Nigeria: The Economics of Cocoa Production and Marketing in Nigeria, 1974.

Arya, L. A.; Myers, D. L.; Jackson, N. D. Dietary caffeine intake and risk for detrusor instability: a case-control study. Obstetrics and Gynecology, v. 96, p. 85-89, 2000.

Asogwa, E. U.; Dongo, L. N. Problems associated with pesticide usage and application in Nigeria cocoa production: A review. African Journal of Agricultural Research, v. 4, no. 8, p. 675-683, 2009.

CRIN. Scientific survey report of the cocoa production hectarage in Nigeria. Unpublished report submitted to the National Cocoa Development Committee. 2008.

Dankyi, E.; Gordon, C.; Carboo, D.; Fomsgaard, I.S. Quantification of neonicotinoid insecticide residues in soils from cocoa plantations using a QuEChERS Extraction procedure and LC-MS/MS. Science of the Total Environment, v. 499, p. 276-283, 2014.

Fadipe, A. E. A.; Adenuga, A. H.; Ilori, T. E. Economic analysis of cocoa production in Oyo State, Nigeria. Nigerian Journal of Agriculture, Food and Environment, v. 8, no. 4, p. 58-63, 2012.

Famuyiwa, B. S.; Torimiro, D. O.; Obatolu, B. O.; Uwagboe, E. O. Preventive measures adopted by Nigerian farmers for the environmental hazards in cocoa plantations. Journal of Agricultural Extension, v. 18, no. 2, p. 99-111, 2014.

Fianko, J. R.; Donkor, A.; Lowor, S. T.; Yeboah, P. O. Agrochemicals and the Ghanaian environment. Journal of Environmental Protection, v. 2, no. 3, p. 221-230, 2011.

Folayan, J. A.; Daramola, G. A.; Oguntade, A. E. Structure and performance evaluation of cocoa marketing institutions in SouthWestern Nigeria: An economic analysis.
Journal of Food, Agriculture and Environment, v. 4, no. 2, p. 123-128, 2006.

Gwary, O. M.; Hati, S. S.; Dimari, G. A.; Ogugbuaja, V. O. Pesticide residues in bean samples from North Eastern Nigeria. ARPN Journal of Science and Technology, v. 2, no. 2, p. 79-84, 2012.

ICCO. Inventory of the health and nutritional attributes of cocoa and chocolate. International Cocoa Organization. PRC/3/4/Rev.1: 2-8, 2001.

Iremiren, G. O. Soil fertility and ageing cocoa farms in Nigeria. A paper presented in World cocoa foundation, 2011. Available at <http://www.worldcocoafoundation.org/wh o-weare/partnershipmeeting>. Accessed on: Oct. 10, 2017.

Lærke, M. Quality assurance along the primary processing chain of cocoa beans from harvesting to export in Ghana. 2010.

Nathanson, J.A. Caffeine and related Methylxanthines: Possible naturally occurring pesticides. Science, New Series, v. 226, no. 4671, p. 184-187, 1984.

Mariyono, J.; Battharai, M. Factors determinants of pesticides use and disease management practices adopted on chili farming in Central Java, Indonesia. 2009. Available from: <https://www.aciar.gov.au/ file/76121/download?token=t3ch8peT $>$.

Accessed on: Oct. 17, 2017.

Mostakim, M.; Khan, A. R. Effect of coffee on the growth and development of the red flour beetle, Tribolium castaneum (Herbst) (Coleoptera: Tenebrionidae). Bangladesh Journal of Zoology, v. 42, no. 2, p. 211-216, 2014.

Mulungu, L. S.; Luwondo, E. N.; Shazia, O.; Reuben, W. M.; Misangu, R. N. Effectiveness of local botanicals as protectants of stored beans (Phaseolus vulgaris L.) against bean bruchid (Zabrotes subfasciatus Boh) (Genera: Zabrotes. Family: Bruchidae). Journal of Entomology, v. 4, p. 210-217, 2007.

Oduwole, O. O. Sustainable cocoa production in Nigeria: Farmers perception of technology characteristics and socio economic factors in adoption decision. Proceedings 13th International Cocoa Research Conference, p. 1147-1152, 2001.

Okoya, A. A.; Torto, N.; Ogunfowokan, A. O.; Asubiojo, O. I. Organochlorine (OC) pesticide residues in soils of major cocoa plantations in Ondo State, Southwestern Nigeria. African 
Journal of Agricultural Research, v. 8, no. 28, p. 3842-3848, 2013.

Olebunne, C. E. Social entrepreneurship: The Nigerian perspective. 2009. Available from: $<$ http://www.africanevents.com>. Accessed on: Dec. 13, 2017.

Owombo, P. T.; Idumah, F. O.; Afolayan, A. F. Assessing factors affecting adherence to safty precautions in pesticides use among cocoa farmers in Nigeria. Ethiopian Journal of Environmental Studies and Management, v. 7, no. 2, 2014. https://doi.org/10.4314/ ejesm.v7i2.1S

PAN Germany. PAN International List of Highly Hazardous Pesticides. Hamburg, 2011. Smith, A. G.; Gangolli, S. D. Organochlorine chemicals in sea food: Occurrence and health concerns. Food and Chemical Toxicology, v. 40, p. 767-779, 2002.
Taubert, D.; Roesen, R.; Schömig, E. Effect of cocoa and tea intake on blood pressure: A meta-analysis. Archives of Internal Medicine, v. 167, no. 7, p. 626-634, 2007.

Tijani A. A.; Sofoluwe, N.A. Factors determining the extent of pesticide use in Nigerian farms. Journal of Agricultural Economics and Development, v.1, no. 1, p. 1-9, 2012.

USDA - United States Department of Agriculture. Nutrient Data Laboratory. 2008. Available from: <http://www.nal.usda.gov/ fnic/foodcomp/search/>. Accessed on: Oct. 12, 2017. 